\title{
Ergonomics and design in the Brazilian agricultural sector: a proposal to build matrix of contradictions
}

\author{
Thaís Tosetto $^{\mathrm{a} *}$ and João Alberto Camarotto ${ }^{\mathrm{b}}$ \\ ${ }^{\mathrm{a} b}$ Industrial Engineer Department, Federal University of São Carlos. Rodovia Washington Luís, Km 235, São \\ Carlos, São Paulo, Brazil.
}

\begin{abstract}
The paper presents a correlation between the parameters of classical TRIZ and variables of analysis of the EWA to construct a matrix of contradictions in ergonomics, with the objective of assisting the designing processes in the Brazilian agricultural sector. Given the representativeness of the sector in the economy, the boundary conditions in which the activities are developed and their impact on the health of workers, this proposal should contribute to the development of adaptable solutions and the promotion of Decent Work.
\end{abstract}

Keywords: agricultural sector, ergonomics, TRIZ, contradiction

\section{Introduction}

Motivated by the need for more flexible production exerted by global competition and the demand for innovation in order to respond quickly to consumer demands with new products and new markets, the restructuring process is not unique to industrial sector, is also experienced in the agriculture industry, with significant impact on the requirements and working conditions.

The agriculture sector employs about half the world's entire workforce, with an estimate of 1.3 billion workers [1].Studies indicates that the agricultural sector is directly responsible for more than 17 million jobs in Brazil, representing about $20 \%$ of the economically active population $[12,15,16]$, and it is the economic foundation of most small and medium sized cities [16]. The value of the agribusiness production is around $30 \%$ of GDP, considering the value of agricultural production and activities outside of production units $[15,16]$.

When dealing with organizations whose focus is agriculture, the development of actions in ergonomics is hampered by a number of peculiarities. Agri- cultural labor is characterized by a strong interdependency between the tasks. The arbitrary allocation of resources by the farmer due in large part [6]: "(...) the limited nature of available resources (land, capital and labor in particular), which forces the farmer to choose how to allocate these resources to different activities: crop rotation, the organization of work, investment choices in equipment are the result of such arbitration. Understanding these arbitrations is important for the ergonomist that seeks to improve working conditions or to those accompanying a process of reorganization of work in a state of transformation of resources "(p.357) [6].

Regarding the regulatory framework, the publication of Norm 17 (NR17), in the 90's, is an important milestone in Brazilian ergonomics, as it strengthens the need for ergonomic actions within the perspectives of AET. However, it is restricted to industrial activities. In rural areas, it should comply with the provisions of NR31, specific to the Rural Area, published in March 2005 and in effect since June 2005, whose determinations are significantly limited in scope. In practice, this differentiation should take

Corresponding author. E-mail: thais.tosetto@gmail.com $1051-9815 / 12 / \$ 27.50$ C 2012 - IOS Press and the authors. All rights reserved 
into account the characteristics of activities, which hinders its effective application.

Agriculture is recognized as one of the most hazardous industries [11], although the work activity and its constraints are less valued and researched. The development of prevention and health activities articulated with the production process is influenced by several factors related to the complexity of work and resource management in this sector, besides the poor performance of the government institutions in terms of support mechanisms, monitoring and regulatory framework [25].

The work, labor-intensive, has high rates of RSI [8], which reflects the materialization in the body of workers of different workloads, material and immaterial, which presents an expressive demand for ergonomics actions aimed, in addition to deepening the knowledge of the activity, the development of solutions to these particularities. In this sense, the proposal aims to integrate tools for analysis and development of projects that can contribute to reducing the impacts of activities on workers' health and productivity of organizations, meeting the goals of the Decent Work agenda in Brazil. In order to develop this integrative approach, it is necessary to summarize the guiding concepts and tools. Interventions in ergonomics in agriculture and the Decent Work agenda in the country are presented in order to contextualize the proposal.

\section{Ergonomics and occupational health in agriculture}

Being a labor intensive production, the agriculture is characterized by high rates of incidence of musculoskeletal injuries. Studies carried out show that agriculture has an almost epidemic incidence of musculoskeletal disorders[8]. The authors show that the presence of musculoskeletal disorders in agriculture is higher, about $100 \%$ to $150 \%$ in relation to any other industry sector in the United States. In most Countries, agriculture is recognized as one of the most hazardous industries [8].

RSIs can incapacitate the workers at rates close to or higher than other diseases [8]. Researchers say the use of ergonomic approaches can help in preventing these diseases, potentially disabling, if the constraints and determinants of work are understood:

reality that presents itself, seek to make feasible the needs for flexibility of the lean enterprise, busi-
Ergonomic Work Analysis (EWA) leads to identify a series of elements that modulate the activity of work, on various levels, with consequences also on several levels. At all times we analyze how the work activity integrates these elements and how different rationalities that constitute the construction of this system are presented [19].

Although proven high rates of RSIs in agriculture, this is not an issue that receives attention from researchers and health professionals and safety in the field.

In addition to the postural constraints, it is important to emphasize the risks chemicals in agriculture. Agricultural Census data from 2006 indicate that more than half of Brazilian agricultural establishments in which there was use of pesticides has received technical guidance and, of these, about $20 \%$ did not use protective equipment $[15,16]$

In France, studies about agricultural work show that "many accidents occur on the crop (...) it is a work whose effort decreased, but still very heavy, and many farmers suffer from various musculoskeletal disorders" (p.358) [6].

The work postures are often determined by the traits of the activities that are often developed outdoors and in large tracts of land. This work which is still considered heavy, either by requirements for manual handling or postural load, is associated with a high demand for attention and implied skills. The know-how is fundamental to the quality assurance process, the cutoff point, the visual control of pests, preparation and maintenance of flower beds and greenhouses and management of variability is a constant demand of this work. To these requirements add the pressures and productivity goals and collective management of labor.

Intervention on the working conditions and health on farms should take into account the fact that few farmers can finance ergonomic actions and these farmers need to perform arbitrations that often involve "a combination of many logics (economic, equity, technical, organizational, ecological ...)" (p.536) [6].

Restructuring production processes, whose transformations in work organization are reflected in the working conditions and people's lives are not unique to the industrial sector, are also present in greater or lesser extent in agriculture, with significant impact on the requirements and work conditions. The administrative innovations, proposed to account for the ness networks, the mobilization of workers, teamwork and customer satisfaction [5] These new forms 
of work intensification in the countryside still live with the administration features expressed by the model of mass production.

\section{The agricultural labor under the decent work perspective}

Analysis of the Agricultural Census 1985, 1995 and 2006 shows that the concentration of land in Brazil remained almost unchanged. However, focusing on the total establishments, $47 \%$ have less than 10 hectares, while those with more than 1000 hectares represent around 1\% $[15,16]$. Small businesses account for $84.36 \%$ of people employed in agricultural establishments. Even though each of them generates few jobs, small establishments employ about 12 times more workers per hectare than the average and 45 times more than large establishments. Still, the results of Census 2006, published by the Federal Government in 2011, reveal the low level of education of agricultural producers. Data show that $80 \%$ of farmers are illiterate or have not completed primary schools. The rates for other levels of education are: $8 \%$ for elementary school, $7 \%$ for mid-level agricultural technician or high school, and only $3 \%$ with higher education.

The technical orientation provided by the government is very limited, reaching only $22 \%$ of establishments and it is related to the educational level of leaders. As an example, concerning producers with education at or below the secondary school, only $16.8 \%$ received assistance, while for producers with complete elementary education this percentage raises to $31.7 \%$ and for producers with higher education, the technical assistance reaches $44.7 \%$ of establishments.

Regarding access to finance, either through banks or government programs, used for funding, investment in real estate and machinery and maintenance of the establishment, there is a preponderance of large producers. Establishments with 1,000 or more hectares captured $43.6 \%$ of the funds, though accounting for only $0.9 \%$ of all establishments which have obtained funding. Those with up to $100 \mathrm{hec}-$ tares, $88.5 \%$ of those that obtained funding in 2006 , captured $30.42 \%$ of the resources $[15,16]$.

Given the importance, especially of small and medium-sized properties in the generation of jobs in the country and all socio-economic, technical and organizational circumstances, the agricultural sector be- comes an important focus for the promotion of Decent Work.

The weak production of inside knowledge about the production process and its relationship with the health-illness processes of workers is reinforced by almost no literature available on the subject. Not knowing this relationship hinders the effective implementation of local actions and the development of public policies.

With regard to agricultural work, a prominent theme in literature and the Brazilian public policy refers to the fact that, despite being responsible for the permanent employment of a significant proportion of the population, it is an industry not traditionally served by health policies and safety at work, it concentrates much of the poor, child labor and forced labor, and it has the highest gender inequalities, which includes this industry in the Decent Work agenda in Brazil.

The International Labor Conference of 1999 defined Decent Work as "opportunities for women and men to obtain decent and productive work in conditions of freedom, equity, security and human dignity" $[23,24]$. Regarding the Health and Safety at Work, the ILO's goal in a period of 10 years, from 2005 to 2015 , is to reduce in $20 \%$ the incidence of accidents and illnesses at work, and extend protection Health and Safety at Work (SST) to sectors traditionally not met, raising the coverage of current protection of $12 \%$ to $25 \%$ [21].

In order that the complexity of the work be learned and interventions are carried out properly and under the perspective of Decent Work agenda it is necessary to make a prognostic about the work that takes into account the double expectation of results in terms of health and productivity. Therefore, the methodology of Ergonomic Work Analysis becomes a prerequisite.

\section{The ergonomic workplace analysis (EWA) under the transformation of labor perspective}

The tool Ergonomic Workplace Analysis (EWA), developed by the Finnish Institute of Occupational Health [1], is being increasingly disseminated, adapted and used in identifying risk factors, after a detailed description of tasks and activities.

Built on the work physiology theories, biomechanics and occupational hygiene, the participatory model of work organization and psychological aspects $[1,7]$ the EWA is a tool that integrates the physical, cogni- 
tive and organizational work, addressed to over 14 categories of analysis.

These categories are analyzed and compared from the point of view of the analyst and workers, by assigning a score ranging from 1 to 5 for the former and a subjective analysis for the latter.

The broadening of the score indicates a departure from the ideal working conditions and may indicate the possibility of damage to health of workers with possible consequences for production, given the integrative characteristic of the activity [13].

The authors $[1,7]$ also reported that the tool can be adapted to become more specific to the situation analyzed and be used to assess changes performed in jobs or tasks.

Table 1 shows the categories of analysis associated with a brief description.

In order to score the items, one must provide a detailed description of the tasks and activities. In the end, it is expected to obtain an overall assessment which indicates the determinants of work situations analyzed, from which can be derived suggestions for improvements. However, the passage of the identification of determinants to the development of adaptable solutions encounters barriers in the agricultural sector, given the complexity of work and the boundary conditions of its implementation.

Like any ergonomic intervention should, by principle, trigger changes in the work $[9,10,13]$, these changes are the development of improvement projects. The AET will contribute to the definition of the determinants of work providing the information needed to develop the project.

The introduction of ergonomics in the design process is presented as an alternative to searching for off-the-shelf solutions to a problem, acknowledging the importance of taking into account the work activity. Whatever the situation, the operators' work never comes down to "simple" execution of procedures [13] and it is up to the ergonomics to shape and optimize the interactions between human and system elements to suit the efficiency requirements, comfort and safety characteristics, capabilities and limitations of those who work.

Authors point the importance of considering in any ergonomic action that: "The farmer is both the designer of the work situation and performer, designer of the security of his property and actor likely to be harmed in their physical integrity, he is whom prescribes the effectiveness sought, but also the operator who must adapt to the variability of situations "(p.539) [6].

Back to the reality of farm work, we see the difficulty of implementing complex projects that take into consideration various rationales, simply because they can be absent within the organizational structure of enterprises. This is a limiting factor to escape from the choices of market solutions or to develop projects that are not trivial and that in fact represent a significant change in working conditions.

The difficulty in the analysis process itself, a prerequisite for the development of solutions, is perpetuated in the design process. This reality, in context here makes it crucial to build a tool to support the process of ergonomics and design within this sector.

Table1: EWA Categories of Analysis

\begin{tabular}{|c|c|}
\hline EWA - Categories of Analysis & Short Description \\
\hline $\begin{array}{l}\text { 1. Work space } \\
\text { 1.1. Horizontal work area } \\
\text { 1.2. Working height } \\
\text { 1.3. Viewing } \\
\text { 1.4. Leg space } \\
\text { 1.5. Seat } \\
\text { 1.6 Hand Tools } \\
\text { 1.7. Other equipment }\end{array}$ & $\begin{array}{l}\text { Assess the adequacy of workspaces to the demands of the activities and characteristics } \\
\text { of workers. It is related to envelopes of reach and the possibilities of alternating pos- } \\
\text { tures }\end{array}$ \\
\hline 2. General Physical Activity & Requests related to physiological and biomechanical recovery time and fatigue \\
\hline 3. Lifting & $\begin{array}{l}\text { Assess the conditions of manual handling of loads. Refers to potentially rick impact on } \\
\text { the joints, especially in the spine. Consider the weight of the manipulated object, the } \\
\text { transport distances, picks conditions and heights in which the movement is performed. } \\
\text { It also includes the distance of the hands and the object relative to the body }\end{array}$ \\
\hline $\begin{array}{l}\text { 4. Work postures and movements } \\
\text { 4.1. Neck-shoulders } \\
\text { 4.2. Elbow-wrist } \\
\text { 4.3. Back }\end{array}$ & $\begin{array}{l}\text { Related to fatigue. Influenced by the duration of labor, the frequency of action, the } \\
\text { methods and equipment available. Workspaces also condition the postures adopted by } \\
\text { workers }\end{array}$ \\
\hline
\end{tabular}




\begin{tabular}{|c|c|}
\hline 4.4. Hips-legs & \\
\hline 5. Accident risk & $\begin{array}{l}\text { Related to the risk of accidents, taking into account the probability of occurrence and } \\
\text { severity of injury to the worker and / or system }\end{array}$ \\
\hline 6. Job content & Related to the number and quality of tasks performed and also the degree of autonomy \\
\hline 7. Job restrictiveness & Related to the influence exerted by the organization of work on the spaces of regulation \\
\hline 8. Work communication and Personal contacts & Related to the possibility of communication and exchange of information on the work \\
\hline 9.Decision-making & $\begin{array}{l}\text { Related to the amount and quality of information available to the worker for the deci- } \\
\text { sion. On the risk involved in the decision and its consequences in terms of health and } \\
\text { production }\end{array}$ \\
\hline 10.Repetitiveness of the work & $\begin{array}{l}\text { Determined by the average length of a repetitive cycle of work. The shorter the cycle } \\
\text { time, the greater the repeatability }\end{array}$ \\
\hline 11.Attentiveness & Related to demand attention and the observation time required for the activity \\
\hline 12.Lighting & $\begin{array}{l}\text { Considers the relationship between the level of demand for luminance and visual acu- } \\
\text { ity task }\end{array}$ \\
\hline 13.Thermal Environment & $\begin{array}{l}\text { Consider the speed and relative humidity, related to the demands of the task. The ther- } \\
\text { mal environment influences the performance of activities and the maintenance of ho- } \\
\text { meostasis. The risks posed by thermal conditions depend on the combined effect of } \\
\text { environmental factors, such as: air temperature, air humidity, air velocity, thermal ra- } \\
\text { diation, the type of activity, workload and the type of used clothing. }\end{array}$ \\
\hline 14.Noise & $\begin{array}{l}\text { Considers the relationship between the noise level of complexity and demands of the } \\
\text { task or verbal communication }\end{array}$ \\
\hline
\end{tabular}

\section{The TRIZ methodology}

The phase of identifying the determinants for the development solutions is not a trivial process, as already pointed out. Solutions that take in account of the complexity of agricultural work are not found in the literature, but can be found in similar areas of knowledge.

Altshuller's Theory of inventive problems defined as those where the solution causes the appearance of new problems, is a common reality in developing projects in ergonomics.

The method TRIZ (The Russian Theory of Inventive Problem Solving) has been widely used in the United States and Europe in recent decades and meets the needs of development and Implementation of improvements in the sector. Developed based on extensive study of thousands of patents, the method identifies 39 engineering parameters that may be in contradiction during the project development. Arranged in a square matrix, the crossing rows and columns regarding the contradictory parameters points out relevant inventive principles, among 40 are identified in the TRIZ study. These principles suggest possible solutions to a given problem $[3,4,18]$, derived from the generalization and clustering solutions repeatedly used in the creation, development and improvement of technical systems of different areas [2].

Summarizing the results of the research, TRIZ recognizes that systems evolve toward ideality basically overcoming technical contradictions with minimal addition of resources. Therefore, to solve creative problem, TRIZ proposes a dialectic way of thinking: (i) understand the problem as a system, (ii) imagine the ideal solution, (iii) resolve the contradictions by using the methodology [4].

The 39 engineering parameters are presented in Table 2 associated with a brief description.

Once the critical parameters to be improved and the parameters that can potentially degrade while the former improve are identified, the contradictions of the system are also found. The correlation between the parameters of Classical TRIZ and the domain of Ergonomics, expressed in this article by the EWA, is expected to provide a framework to negotiate the development of solutions based on the identified determinants.

Table2: TRIZ Engineering Parameters. Source: http://www.kcg.com.sg/triz-39-parameters-contradiction.html

\begin{tabular}{|c|l|l|}
\hline 1 & Weight of moving object & $\begin{array}{l}\text { The mass of the object, in a gravitational field. The force that the body exerts on its support } \\
\text { or suspension. }\end{array}$ \\
\hline 2 & Weight of stationary object & $\begin{array}{l}\text { The mass of the object, in a gravitational field. The force that the body exerts on its support } \\
\text { or suspension, or on the surface on which it rests. }\end{array}$ \\
\hline 3 & Length of moving object & Any one linear dimension, not necessarily the longest, is considered a length. \\
\hline 4 & Length of stationary object & Same. \\
\hline
\end{tabular}




\begin{tabular}{|c|c|c|}
\hline 5 & Area of moving object & $\begin{array}{l}\text { A geometrical characteristic described by the part of a plane enclosed by a line. The part of a } \\
\text { surface occupied by the object. OR the square measure of the surface, either internal or ex- } \\
\text { ternal, of an object. }\end{array}$ \\
\hline 6 & Area of stationary object & Same \\
\hline 7 & Volume of moving object & $\begin{array}{l}\text { The cubic measure of space occupied by the object. Length } \mathrm{x} \text { width } \mathrm{x} \text { height for a rectangular } \\
\text { object, height } \mathrm{x} \text { area for a cylinder, etc. }\end{array}$ \\
\hline 8 & Volume of stationary object & Same \\
\hline 9 & Speed & The velocity of an object; the rate of a process or action in time. \\
\hline 10 & Force & $\begin{array}{l}\text { Force measures the interaction between systems. In Newtonian physics, force }=\text { mass } X \\
\text { acceleration. In TRIZ, force is any interaction that is intended to change an object's condi- } \\
\text { tion. }\end{array}$ \\
\hline 11 & Stress or pressure & Force per unit area. Also, tension. \\
\hline 12 & Shape & The external contours, appearance of a system. \\
\hline 13 & $\begin{array}{l}\text { Stability of the object's composi- } \\
\text { tion }\end{array}$ & $\begin{array}{l}\text { The wholeness or integrity of the system; the relationship of the system's constituent ele- } \\
\text { ments. Wear, chemical decomposition, and disassembly are all decreases in stability. In- } \\
\text { creasing entropy is decreasing stability. }\end{array}$ \\
\hline 14 & Strength & $\begin{array}{l}\text { The extent to which the object is able to resist changing in response to force. Resistance to } \\
\text { breaking. }\end{array}$ \\
\hline 15 & $\begin{array}{l}\text { Duration of action by a moving } \\
\text { object }\end{array}$ & $\begin{array}{l}\text { The time that the object can perform the action. Service life. Mean time between failure is a } \\
\text { measure of the duration of action. Also, durability. }\end{array}$ \\
\hline 16 & $\begin{array}{l}\text { Duration of action by a stationary } \\
\text { object }\end{array}$ & Same. \\
\hline 17 & Temperature & $\begin{array}{l}\text { The thermal condition of the object or system. Loosely includes other thermal parameters, } \\
\text { such as heat capacity, that affect the rate of change of temperature. }\end{array}$ \\
\hline 18 & Illumination intensity * (jargon) & $\begin{array}{l}\text { Light flux per unit area, also any other illumination characteristics of the system such as } \\
\text { brightness, light quality, etc.. }\end{array}$ \\
\hline 19 & Use of energy by moving object & $\begin{array}{l}\text { The measure of the object's capacity for doing work. In classical mechanics, Energy is the } \\
\text { product of force times distance. This includes the use of energy provided by the super- } \\
\text { system (such as electrical energy or heat.) Energy required to do a particular job. }\end{array}$ \\
\hline 20 & Use of energy by stationary object & Same \\
\hline 21 & Power* (jargon) & The time rate at which work is performed. The rate of use of energy. \\
\hline 22 & Loss of Energy & $\begin{array}{l}\text { Use of energy that does not contribute to the job being done. See } 19 \text {. Reducing the loss of } \\
\text { energy sometimes requires different techniques from improving the use of energy, which is } \\
\text { why this is a separate category. }\end{array}$ \\
\hline 23 & Loss of substance & $\begin{array}{l}\text { Partial or complete, permanent or temporary, loss of some of a system's materials, sub- } \\
\text { stances, parts, or subsystems. }\end{array}$ \\
\hline 24 & Loss of Information & $\begin{array}{l}\text { Partial or complete, permanent or temporary, loss of data or access to data in or by a system. } \\
\text { Frequently includes sensory data such as aroma, texture, etc. }\end{array}$ \\
\hline 25 & Loss of Time & $\begin{array}{l}\text { Time is the duration of an activity. Improving the loss of time means reducing the time taken } \\
\text { for the activity. "Cycle time reduction" is a common term. }\end{array}$ \\
\hline 26 & Quantity of substance/the matter & $\begin{array}{l}\text { The number or amount of a system's materials, substances, parts or subsystems which might } \\
\text { be changed fully or partially, permanently or temporarily. }\end{array}$ \\
\hline 27 & Reliability & A system's ability to perform its intended functions in predictable ways and conditions. \\
\hline 28 & Measurement accuracy & $\begin{array}{l}\text { The closeness of the measured value to the actual value of a property of a system. Reducing } \\
\text { the error in a measurement increases the accuracy of the measurement. }\end{array}$ \\
\hline 29 & Manufacturing precision & $\begin{array}{l}\text { The extent to which the actual characteristics of the system or object match the specified or } \\
\text { required characteristics. }\end{array}$ \\
\hline 30 & External harm affects the object & Susceptibility of a system to externally generated (harmful) effects. \\
\hline 31 & Object-generated harmful factors & $\begin{array}{l}\text { A harmful effect is one that reduces the efficiency or quality of the functioning of the object } \\
\text { or system. These harmful effects are generated by the object or system, as part of its opera- } \\
\text { tion. }\end{array}$ \\
\hline 32 & Ease of manufacture & $\begin{array}{l}\text { The degree of facility, comfort or effortlessness in manufacturing or fabricating the ob- } \\
\text { ject/system. }\end{array}$ \\
\hline 33 & Ease of operation & $\begin{array}{l}\text { Simplicity: The process is NOT easy if it requires a large number of people, large number of } \\
\text { steps in the operation, needs special tools, etc. "Hard" processes have low yield and "easy" } \\
\text { process have high yield; they are easy to do right. }\end{array}$ \\
\hline 34 & Ease of repair & $\begin{array}{l}\text { Quality characteristics such as convenience, comfort, simplicity, and time to repair faults, } \\
\text { failures, or defects in a system. }\end{array}$ \\
\hline 35 & Adaptability or versatility & $\begin{array}{l}\text { The extent to which a system/object positively responds to external changes. Also, a system } \\
\text { that can be used in multiple ways for under a variety of circumstances. }\end{array}$ \\
\hline 36 & Device complexity & $\begin{array}{l}\text { The number and diversity of elements and element interrelationships within a system. The } \\
\text { user may be an element of the system that increases the complexity. The difficulty of master- } \\
\text { ing the system is a measure of its complexity. }\end{array}$ \\
\hline 37 & Difficulty of detecting and measur- & Measuring or monitoring systems that are complex, costly, require much time and labor to \\
\hline
\end{tabular}




\begin{tabular}{|c|l|l|}
\hline & ing & $\begin{array}{l}\text { set up and use, or that have complex relationships between components or components that } \\
\text { interfere with each other all demonstrate "difficulty of detecting and measuring." Increasing } \\
\text { cost of measuring to a satisfactory error is also a sign of increased difficulty of measuring. }\end{array}$ \\
\hline 38 & Extent of automation & $\begin{array}{l}\text { The extent to which a system or object performs its functions without human interface. The } \\
\text { lowest level of automation is the use of a manually operated tool. For intermediate levels, } \\
\text { humans program the tool, observe its operation, and interrupt or re-program as needed. For } \\
\text { the highest level, the machine senses the operation needed, programs itself, and monitors its } \\
\text { own operations. }\end{array}$ \\
\hline 39 & Productivity & $\begin{array}{l}\text { The number of functions or operations performed by a system per unit time. The time for a } \\
\text { unit function or operation. The output per unit time, or the cost per unit output. }\end{array}$ \\
\hline
\end{tabular}

\section{Preliminary correlation}

The Correlation Between the parameters of classical TRIZ and categories of analysis of the EWA, in order that they can be used in designing processes that involves requirements of ergonomics, with the intention that the risk factors can be dealt with by equating the criteria for health and productivity, often conflicting.

Table 3 shows the proposed correlation.

Table3: Preliminary Correlation

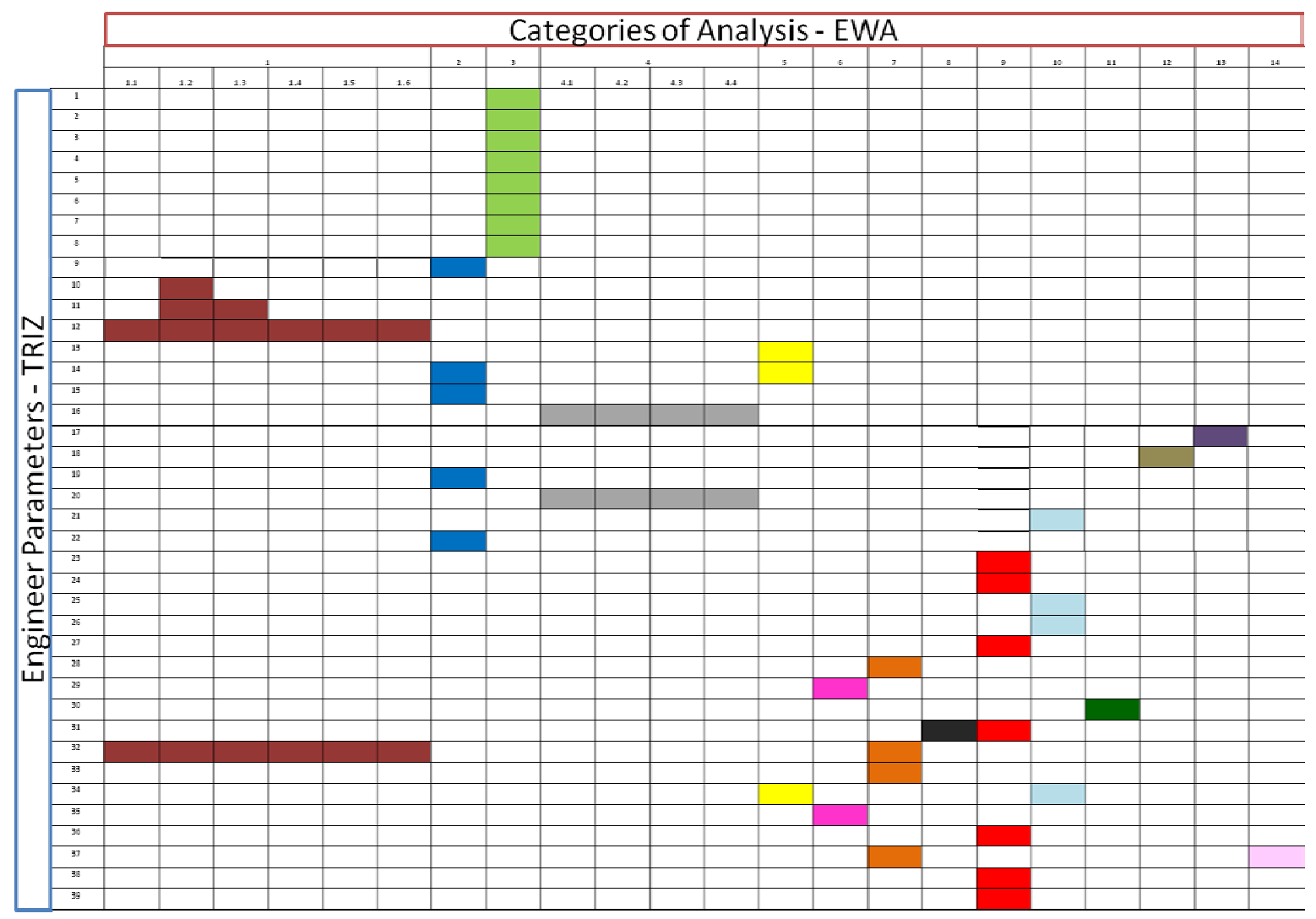

\section{Final Considerations}

This study limited itself to present the initial correlation between the parameters of Classical TRIZ and categories of analysis of the EWA. The next step is to construct, from the correlation between parameters, a square matrix with the 14 categories of analysis showing the inventive principles suggested for each 
contradiction. This job requires a thorough study of the 40 principles in context to the demands of the agricultural sector.

Being labor intensive and characterized by savoirfaire of the farmers, the agricultural sector is characterized by high rates of RSIs. Of critical importance in socio-economic context, given the high rates of employment, agricultural labor in Brazil is a key focus for the Decent Work agenda in the country. However, its characteristics in terms of production process, low level of education associated with lack of technical support by government and weak regulatory framework, make it necessary to develop tools that facilitate the promotion of activities in ergonomics and occupational health. The proposed construction of an array of contradictions in ergonomics is based in this context and seeks to make it accessible not only knowledge of the activity and the identification of determinants, but also mechanisms to support the process of developing solutions.

It is believed that the greatest potential for selfemployment and decent jobs are in rural areas [26]. However, it is necessary to highlight the need for changes in the regulatory framework and public policies related to rural work so that farmers have access to training, technology and technical support.

\section{References}

[1] Ahonen, M.; Launis M.; Kuorinka, T. Ergonomics Workplace Analysis, Helsinki: The Finnish Institute of Occupational Health, 1989.

[2] Akabane, G.; Farias, O. O. and Neto, M. S. N. Supply chain improvement for a forklift distributor. Triz Journal, 2008.

[3] Akay, D., Demray, A. and Kurt, M. Collaborative tool for solving human factors problems in the manufacturing environment: the Theory of Inventive Problem Solving Technique (TRIZ) method. International Journal of Production Research, Vol. 46, No. 11, 2008, pp. 2913 - 2925.

[4] Altshuller, G. The innovation algorithm: TRIZ, systematic innovation, and technical creativity. Worchester, Massachusetts: Technical Innovation Center, 1999.

[5] Boltanski, L.; Chiapello, E. O novo espírito do Capitalismo. São Paulo: WMF Martins Fontes, 2009.

[6] Cerf, M.; Sagory, P. Agricultura e desenvolvimento agrícola. In: Falzon, P. Ergonomia. São Paulo: Edgard Blücher, 2007.

[7] Camarotto, J. A. (Org.). Análise ergonômica do posto de trabalho. São Carlos: Universidade Federal de São Carlos, [199-].
[8] Chapman, L.; Meyers, J. Ergonomics and Musculoskeletal Injuries in Agriculture: Recognizing and Preventing the Industry's Most Widespread Health and Safety Problem. National Agricultural Safety Database, 2001.

[9] Dejours, C. Epistemologia Concreta e Ergonomia. In: Daniellou, F. (org). A ergonomia em busca de seus princípios: debates epistemológicos. São Paulo: Edgard Blucher, 2004.

[10] Falzon, P. Os objetivos da ergonomia. In: Daniellou, F. (org). A ergonomia em busca de seus princípios: debates epistemológicos. São Paulo: Edgard Blucher, 2004.

[11] Fathallah, F. A. Musculoskeletal disorders in labor-intensive agriculture. Applied Ergonomics, Issue 41, pp. 738-743, 2010.

[12] Gasquez, J. G.; Rezende, G. C.; Villa Verde, C. M.; Conceição, J. C. P. R.; Carvalho, J. C. S.; Salerno, M. S. Desempenho e crescimento do agronegócio no Brasil. Brasília: IPEA/DISET, 2004.

[13] Guérin, F.; et al. Compreender o trabalho para transformá-lo: a prática da ergonomia. São Paulo: Edgard Blucher, 2001.

[14] IBGE - Instituto Brasileiro de Geografia e Estatística. Pesquisa nacional por amostra de domicílios 2005 - Síntese dos indicadores. Rio de Janeiro: Ministério do Planejamento, Orçamento e Gestão, 2005.

[15] IBGE - Instituto Brasileiro de Geografia e Estatística. Censo Agropecuário 2006: resultados preliminares. Rio de Janeiro: Ministério do Planejamento, Orçamento e Gestão, 2011.

[16] IBGE - Instituto Brasileiro de Geografia e Estatística. Censo Agropecuário 2006: IBGE revela o retrato do Brasil agrário. Rio de Janeiro: Ministério do Planejamento, Orçamento e Gestão, 2011.

[17] Lourenzani, W.L. Modelo dinâmico para a gestão integrada da agricultura familiar. 2005. 210p. Tese (Doutorado em Engenharia de Produção). Universidade Federal de São Carlos. São Carlos.

[18] Mann, D. L. Better technology forecasting using systematic innovation methods, Technology Forecast Soc., Issue 70, pp. 779-795, 2003.

[19] Montedo, U.; Sznelwar, L. I. Análise ergonômica do trabalho agrícola familiar na produção de leite. Produção. São Paulo. v. 18 , n. 1, p. 142-154, Jan./Abr., 2008.

[20] OIT. Agenda Nacional de Trabalho Decente. Brasília, 2006.

[21] OIT. Trabalho decente nas Américas: uma agenda hemisférica 2006-2015. Brasília, 2006.

[22] OIT. Declaração da OIT sobre os princípios e direitos fundamentais no trabalho e seu seguimento. Brasília, 2007.

[23] OIT. Emprego, desenvolvimento humano e trabalho decente: a experiência brasileira recente. Brasília, 2008.

[24] OIT. Oficina de Consulta Tripartite sobre Indicadores de Trabalho Decente para o Brasil. Brasília, 2009.

[25] O'Neill, D. H. Ergonomics in industrially developing countries: does its application differ from that in industrially advanced countries? Applied Ergonomics, Issue 31, pp. 631-640, 2000.

[26] Sachs, I. Inclusão social pelo trabalho decente: oportunidades, obstáculos, políticas públicas. Estudos Avançados, v. 18, 2004.

[27] http://www.kcg.com.sg/triz-39-parameters-contradiction.html 